\title{
DESIGNING GREEN FAÇADES AND LIVING WALL SYSTEMS FOR SUSTAINABLE CONSTRUCTIONS
}

\author{
KATIA PERINI ${ }^{1} \&$ MARC OTTELÉ ${ }^{2}$ \\ ${ }^{1}$ Department of Architectural Sciences, University of Genoa, Italy. \\ ${ }^{2}$ Faculty of Civil Engineering and Geosciences, Delft University of Technology, The Netherlands.
}

\begin{abstract}
The integration of vegetation in urban areas is a constantly evolving research field. However, green envelopes (especially the most innovative vertical greening systems) are not yet fully accepted as an environmental quality restoration and energy-saving method for the built environment, due to the lack of data needed to quantify their effects and to evaluate the real sustainability (environmental and economic) of these. The many systems available on the market allow combining nature and built space to improve the environmental quality in urban areas; green façades, living wall systems offer more surfaces with vegetation and, at the same time, contribute to the improvement of the thermal performance of buildings. From a functional point of view, vertical greening systems often demand a complex design, which must consider a major number of variables. In the case of vertical greened surfaces, there are numbers of systems to green façades with or without windows, starting from a simple disposition of climbing plants at the base of the façade. Vertical greening systems' characteristics and materials involved can either positively or negatively influence theirs performances, with respect to the improvement of the building envelope efficiency and microclimate conditions (cooling potential and the insulation properties), and the environmental burden produced during their life span (installation, maintenance, disposal, etc.). This paper analyses characteristics, advantages and critical aspects of four common vertical greening systems, with special attention to micro-scale benefits (the benefits most related to the systems peculiarities) and to environmental sustainability.
\end{abstract}

Keywords: Green façade, living wall system, building envelope, thermal behaviour, energy saving, environmental sustainability.

\section{INTRODUCTION}

The integration of vegetation can be an opportunity to address environmental issues of dense urban surroundings [1] with lack of green zones, becoming the scene of important environmental issues relative to pollution in the atmosphere with consequences on the physical well-being and comfort of the local inhabitants $[2,3]$. The many systems available on the market allow combining nature and built space to improve the environmental quality in urban areas and to retrofit the wide building heritage - which is often unsuitable and cause relevant energy waste and discomfort conditions with respect to architectural, functional and performance aspects [3-5].This is an important field to investigate since data show that architecture plays an important role in the field of sustainability. In fact, the building sector has one of the greatest impacts on the environment; buildings consume a significant amount of energy over their life cycle and generate $40-50 \%$ of the total output of greenhouse gases [6-8].

This topic offers the potential to learn from traditional architecture, the earliest form of vertical gardens dates from 2000 years ago in the Mediterranean region and ornamental roof gardens have been developed initially by the civilization of the Tigri and Euphrates River valleys (the most famous examples of witch were the Hanging Gardens of Babylon in the seventh and eight centuries BC $[2,3])$. Several examples of green envelopes, back to 18-19th century, can be found in Northern European regions (Fig. 1), such as climbing plants to shade vertical surfaces in Mediterranean regions, due to the cooling potential of vegetation and the insulation properties (thermal capacity). The cooling capacity of vegetation was also used inside courtyards or patios of traditional houses in 


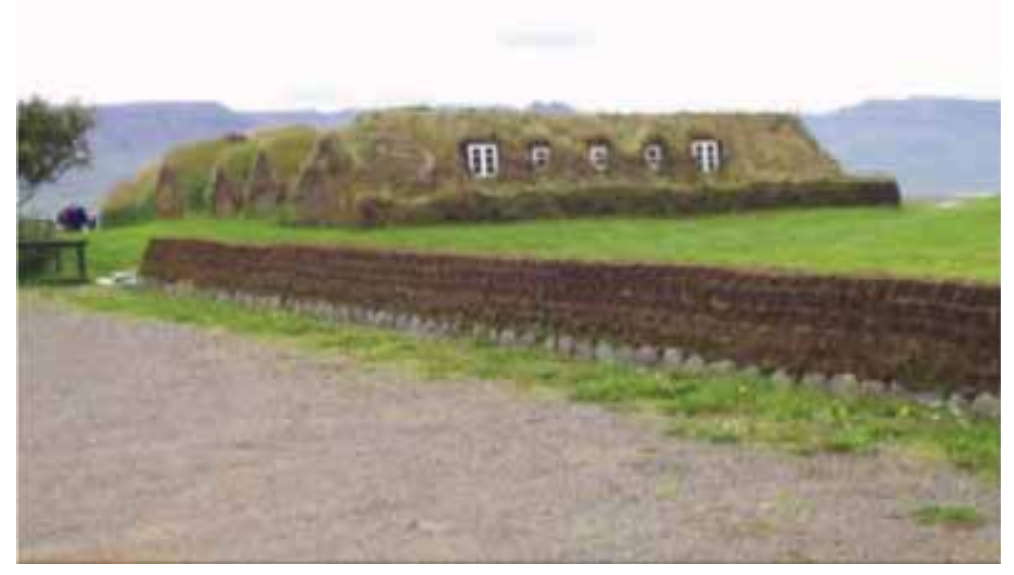

Figure 1: Traditional green envelope (Iceland).

the Mediterranean region to enhance interior ventilation, thanks to the temperature difference between the greened area and the exterior. Nowadays, this kind of building envelope also incorporates advanced materials and other technologies to promote sustainable building functions [2].

The integration of vegetation is a constantly evolving research field; the interest on the (more or less) innovative vertical and horizontal greening systems of architects, planners, citizens and researchers is growing, as well as the number of publications and researches, done to evaluate the positive effects of vegetation to improve the environmental quality [2]. However, the systems for the integration of vegetation (especially the most innovative vertical greening systems) are not yet fully accepted as an environmental quality restoration and energy-saving method for the built environment, due to the lack of data needed to quantify their effects and to evaluate the real sustainability (environmental and economic) of these.

A research conducted by Perini [9] on all the numbers published from 2000 to 2010 of the architectural journals 'Domus' and 'The Architectural Review' found an interest increased for the integration of vegetation in architecture in the last 5-6 years. This can be related not only to a more sustainable approach to improve building efficiency and environmental conditions but also to an aesthetic intention aimed to show projects as sustainable, exploiting green as ecological element par exellence. Therefore, it is important to specify, especially in this period in which an endless number of products and projects are promoted and tagged as eco-friendly, that the concept of sustainability implies the consideration of many factors [10]. The requirements considered for the evaluation of materials and technologies have to rely not only on the analysis of the performances for accomplishing functional and architectonical characteristics they also concern the answer to the global needs of the whole community, with respect to the sustainable use of resources, the control of the productive thread and the valorization of ecosystem services [11].

This paper provides a perspective on some vertical greening systems with respect to the possible improvement of the building envelope efficiency in the field of environmental sustainability. The several systems available on the market have different characteristics (layers involved, plant species, maintenance needs, etc.), which influence the cooling potential and the insulation properties besides their aesthetic effect, functional aspects and the environmental burden produced during their life span. The analysis of the different characteristics, advantages and critical aspects of vertical greening 
systems considers the complexity of these systems and the potential improvement of building envelope efficiency brought by vertical gardens during their life span.

\section{VERTICAL GREENING SYSTEMS AND THEIR CHARACTERISTICS}

There are several possible integration modalities of green elements in architecture. These can have a major or a minor influence on the project conception and on the formal and functional characteristics. Besides in contemporary architecture, it can seem improper to distinguish between horizontal and vertical surfaces. However, greening systems adopt different technologies for vertical green or green roofs, even if flexibility is admitted.

The application of vegetation of a building's vertical skin can drastically change its aesthetics and it allows to obtain a new architectural identity, in the case of the wide building heritage recently built, which finds itself with formal and aesthetic problems [5, 11]. From a functional point of view, vertical greening systems, compared with other typologies of integration, demand a more complex design, which must consider a major number of variables [12]. In the case of vertical greened surfaces, there are numbers of systems to green façades with or without windows, starting from a simple disposition of climbing plants at the base of the façade, as shown in Fig. 2. Small or medium size shrubs can be used to cover a wall with a structure holding planter boxes (Fig. 3). Thin panels can support the grown of many different plants, which strongly characterize the building envelope aesthetically, as in the Caixa Forum designed by Herzog and de Meuronand Patrick Blanc (Fig. 4).

Vertical green can be classified as façade greening or living wall systems (LWS) according to the growing method employed $[2,3]$. Green façades use climbers attached directly to the building surface (a), as in traditional architecture, or supported by cables or trellis (Fig. 5b). Climbers planted on the base of the building provide a relatively inexpensive façade greening. Climbers, although, imply extra work in case of damages, and maintenance of the façade. When planning a green façade with this method, it is important to consider that some climbing plants can grow a few meters high [3]. The plant choice also affects the aesthetical and functional aspects of a greened façade [3].

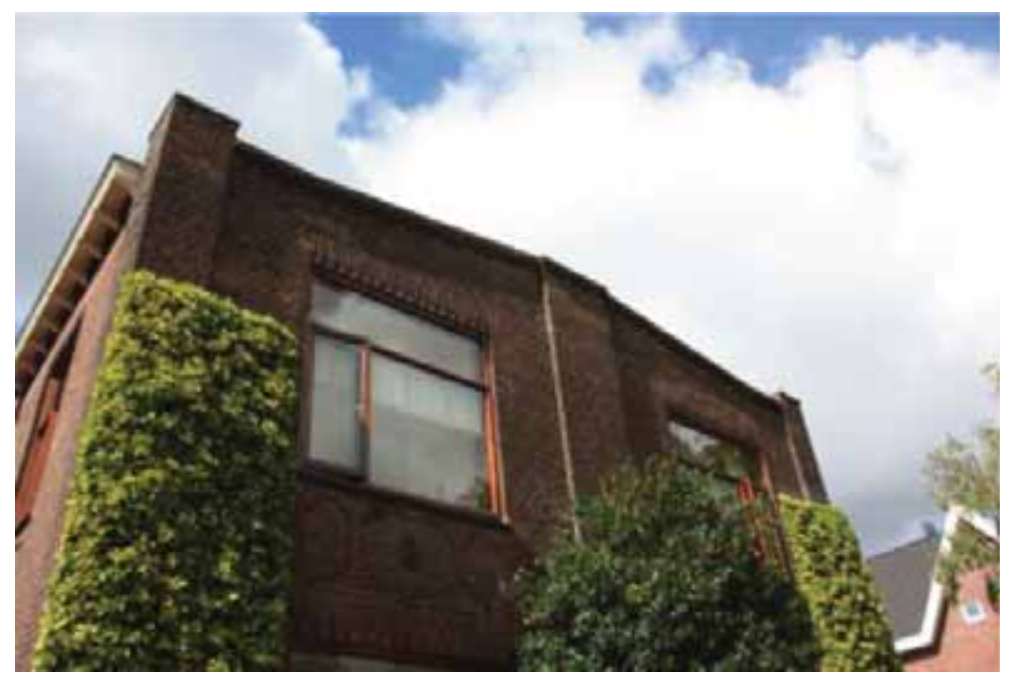

Figure 2: Hedera helix growing on a building façade in Delft (The Netherlands). 
34 Katia Perini \& Marc Ottelé, Int. J. of Design \& Nature and Ecodynamics. Vol. 9, No. 1 (2014)

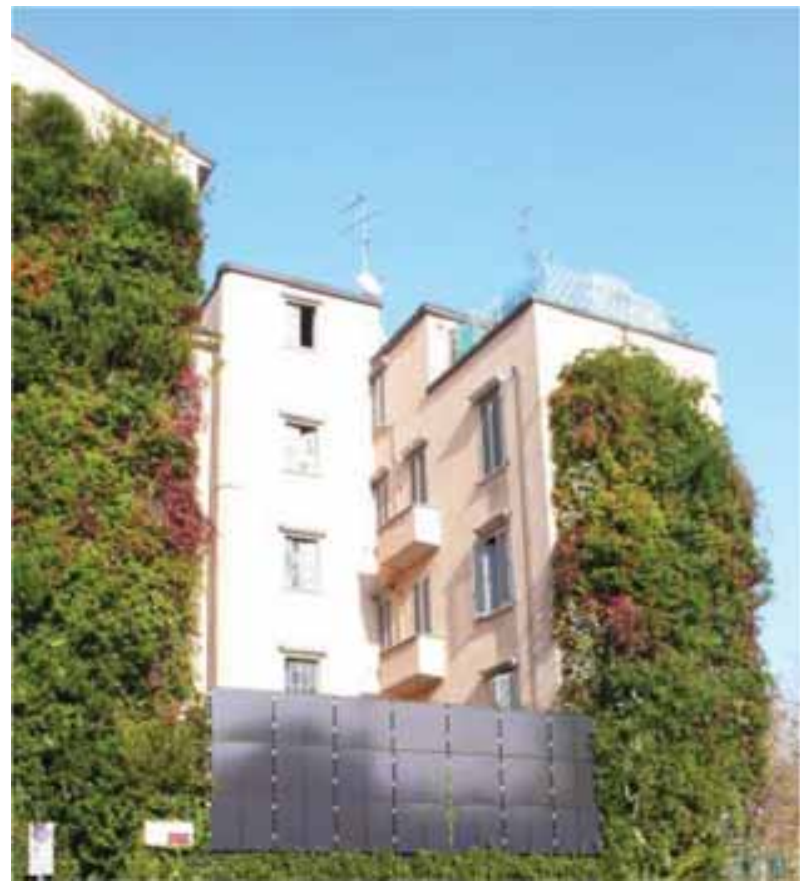

Figure 3: Green wall designed by Temprano in Milan (Italy).

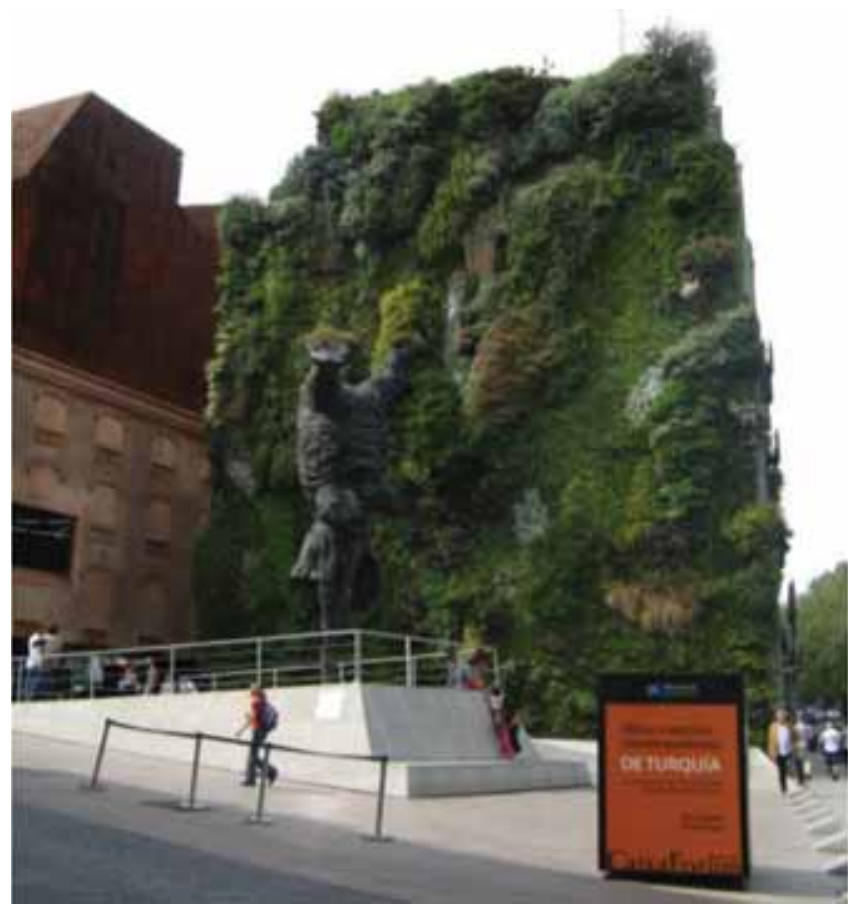

Figure 4: Caixa Forum vertical garden, Patrick Blanc (Madrid, Spain). 

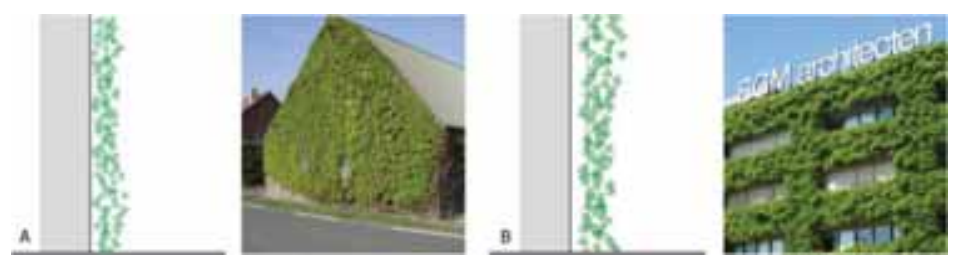

Figure 5: Green façade based on climbers (a) attached directly to the building surface and (b) supported by cables.

An evergreen plant protects the façade from wind flow, snow and rain in winter seasons, which can be relevant especially in temperate climates or north-facing facades. A deciduous climber allows the building envelope to change visually and affects its performances. This type of vegetation is more suitable for Mediterranean climates. In Mediterranean areas, in fact, it is often unnecessary even during winter to have a protection against adverse atmospheric conditions as sun radiation can warm up the building envelope [13].

In a second case scenario, where an indirect greening system is applied, vegetation is supported by cables or meshes. In this occurrence, many materials can be used as support for climbing plants such as steel (coated steel, stainless steel, galvanized steel), different types of wood, plastic or aluminium. Each of the materials enumerated changes the aesthetical and functional properties due to different weight, profile thickness, durability and cost $[12,14]$.

LWSs, which are also known as green walls and vertical gardens, are constructed from modular panels, which contain soil or other artificial growing mediums, for example foam, felt, perlite and mineral wool. Panels require hydroponic cultures using balanced nutrient solutions to provide all or part of the plant's food and water requirements [3]. The plants used for LWS are different type of evergreen small shrubs, offering much more creative and aesthetical potential.

These systems usually employ evergreen plants as small shrubs, which do not naturally grow vertically. Different kinds of LWS have been developed in the last few years. Each one has specific characteristics, starting from the growing medium. Four types of LWS with different principles of growing and planning are shown in Fig. 6: the LWS based on plastic planter boxes (HDPE) is filled with potting soil (c), the LWS based on several felt layers (d), working as substrate and water proofing, supported by a PVC sheet, the LWS based on a foam substrate with steel baskets as support (e) and the LWS based on mineral wood is covered by fleece supported by a metal frame (f).

Considering the large amount of systems available on the market in all Europe, it is possible to give an idea of the costs needed for installing the systems described [15].

Range of costs for vertical greening systems per $\mathrm{m}^{2}$ (in Euros):

a. Direct greening system (grown climbing plants): $30-45 € / \mathrm{m}^{2}$.

b. Indirect greening system (grown climbing plants + supporting material): $40-75 € / \mathrm{m}^{2}$.

c. Indirect greening system with planter boxes (LWS):

- Zinc-coated steel (galvanized steel) $600-800 € / \mathrm{m}^{2}$.

- Coated steel $400-500 € / \mathrm{m}^{2}$.

- HDPE $100-150 € / \mathrm{m}^{2}$.

d. LWS based on planter boxes HDPE: $400-600 € / \mathrm{m}^{2}$.

e. LWS based on foam substrate: $750-1200 € / \mathrm{m}^{2}$.

f. LWS based on felt layers: $350-750 € / \mathrm{m}^{2}$. 

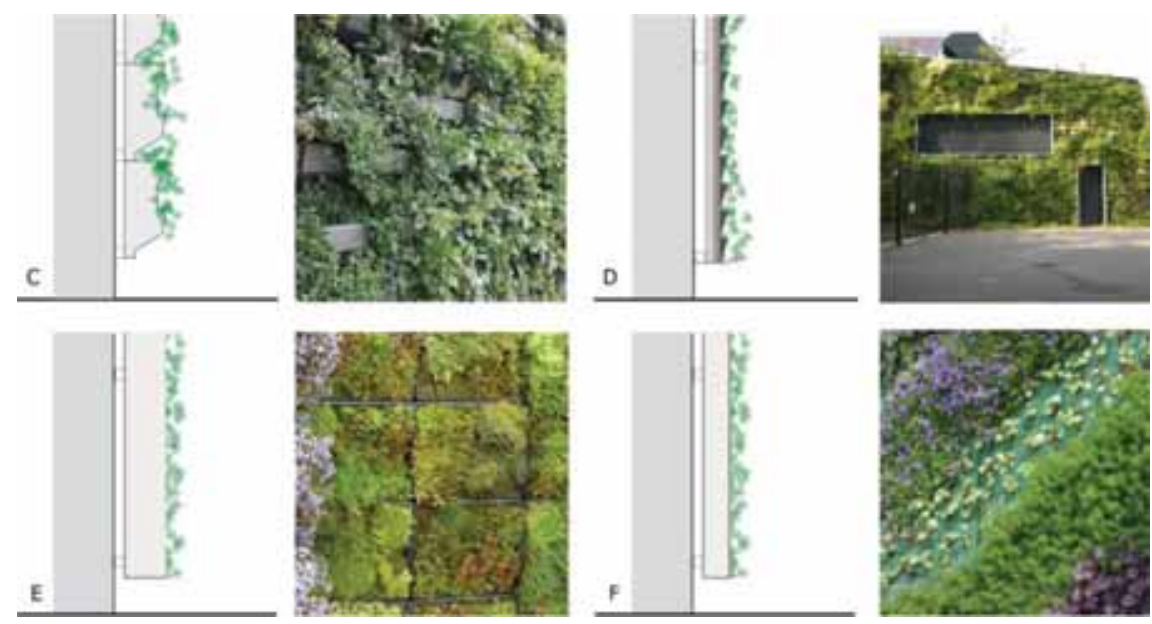

Figure 6: Living wall system based on (c) planter boxes, (d) felt layers, (e) foam substrate and (f) mineral wool.

Inside the range given, the costs depend on the façade surface (equipment) and height, location, connections, etc. It is clear that the LWSs are much more expensive than the direct and indirect greening systems; this is due to the maintenance needed (nutrients and watering system), the materials involved and the design complexity.

It is important to take into account also the durability of the systems. The durability of LWSs varies according to the type of system available. LWSs with panels based on felt layers have an average life expectancy of 10 years, and LWSs based on planter boxes last more than 50 years. A thorough design (details of window ledges, doors, etc.) is always necessary to avoid damages, as corrosion or rot, caused by leakage of water and nutrients [16]. The green layer also results in a shading effect, which reduces the amount of UV light that will fall on building materials; since UV light deteriorates the material and mechanical properties of coatings, paints, plastics, etc., plants will also have an effect on durability aspects [17].

\section{IMPROVING THE BUILDING ENVELOPE EFFICIENCY WITH VERTICAL GREENING SYSTEMS}

Green façades and living walls systems can improve the (local) environment in cities. They offer more surfaces with vegetation and, at the same time, contribute to the improvement of the thermal performance of buildings [16, 18]. The use of horizontal and vertical green has an important impact on the thermal performance of buildings and on the effect of the urban environment as well, both in summer and winter. Plants are functioning as a solar filter and prevent the adsorption of heat radiation of building materials extensively.

By constructing green façades and green roofs, great quantities of solar radiation will be adsorbed for the growth of plants and their biological functions. Especially in dense and paved urban areas, the impact of evapotranspiration and shading of plants can significantly reduce the amount of heat that would be re-radiated by façades and other hard surfaces [19].

To optimize the insulation value of vertical greened surfaces, Krusche et al. [19], Peck et al. [20], Minke et al. [21] and Perez et al. [22] suggested some possible ways: 
- By covering the building with vegetation, the summer heat is prevented from reaching the building skin (shadow), and in the winter, the internal heat is prevented from escaping, reflected or absorbed.

- Thermal insulation provided by vegetation, substrates and configuration (if used for LWS).

- By trapping an air layer within the plant foliage, since wind decreases the energy efficiency of a building by $50 \%$, a plant layer will act as a buffer that keeps wind from moving along a building surface.

- Cooling of air due to evapotranspiration of plants and substrates (if used).

Leaf cover on outside walls, also known as green façades or vertical green, is discussed in many studies. In the beginning of the 1980s, Krusche et al. [19] estimate the thermal transmittance of a 160 mm plant cover at $2.9 \mathrm{Wm}^{-2} \mathrm{~K}^{-1}$. Also Minke et al. [23] suggested some ideas to reduce the exterior coefficient of heat transfer. By reducing the wind speed along a green façade, they suggested that the exterior coefficient of heat transfer of $25.0 \mathrm{Wm}^{-2} \mathrm{~K}^{-1}$ can be lowered to $7.8 \mathrm{Wm}^{-2} \mathrm{~K}^{-1}$, which is comparable to the interior coefficient of heat transfer.

Field measurements performed by Bartfelder and Köhler [24] show a temperature reduction at the green façade in a range of $2-6^{\circ} \mathrm{C}$ compared with a bare wall. Holm [25] shows with field measurements and his DEROB computer model the thermal improvement potential of leaf covered walls. Also Eumorfopoulou and Kontoleon [26] reported the temperature cooling potential of plant covered walls in a Mediterranean climate; the effect was up to $10.8^{\circ} \mathrm{C}$. Another study by Wong et al. [17] on a free standing wall in Hortpark (Singapore) with vertical greening types shows a maximum reduction of $11.6^{\circ} \mathrm{C}$.

Perini et al. [27] show the influence of a green layer on the reduction of the wind velocity along the surface of a building. An extra stagnant air layer in optimal situations can be created inside the foliage, so that when the wind speed outside is the same as inside $\mathrm{R}_{\text {exterior }}$ can be equalized to $\mathrm{R}_{\text {interior }}$. In this manner, the building's thermal resistance can be increased by $0.09 \mathrm{~m}^{2} \cdot \mathrm{K}^{\prime} \cdot \mathrm{W}^{-1}$. These results refer to the wind speed measured at a façade covered by a well-grown direct greening system (Fig. 5a) and a LWS based on planter boxes (Fig. 6c); in the case of LWSs the insulation properties change according to the materials used. The thermal resistance of a LWS based on planter boxes is also influenced by the wind reduction, besides the thermal resistance of the system itself contributes to the thermal resistance and is estimated up to $\mathrm{R}=0.52 \mathrm{~m}^{2} \cdot \mathrm{K} \cdot \mathrm{W}^{-1}$. For both green façades and LWSs, these results imply potential energy savings for building envelopes in warmer and colder climates $[16,27]$. This 'technical/thermal green' strategy of increasing exterior insulation properties of vertical surfaces stimulates upgrading or retrofitting of existing (under-insulated) façades without the added cost of interior or traditional exterior insulation systems.

\subsection{Quantifying the thermal behaviour of different vertical greening concepts}

An experimental research conducted by Ottelé [16] was set up to in order to classify the thermal benefits of green façades or plant covered cladding systems under boundary conditions in a so-called hotbox testing facility.

For this reason, an insulated (mineral wool) cavity wall with different (attached) vertical greening systems was build and tested in order to distinguish the thermal effect of the green systems. In total, there were two measurements performed with Hedera helix (direct and indirect to the wall) and four measurements were carried out with LWSs (based on felt layers, planter boxes, mineral wool and foam substrate), see Table 1.

In the study by Ottelé [16], it was found that, both for the direct and indirect greening principle (Fig. 5), lower surface temperatures of the exterior masonry were measured during summer conditions compared with the bare wall situation. 


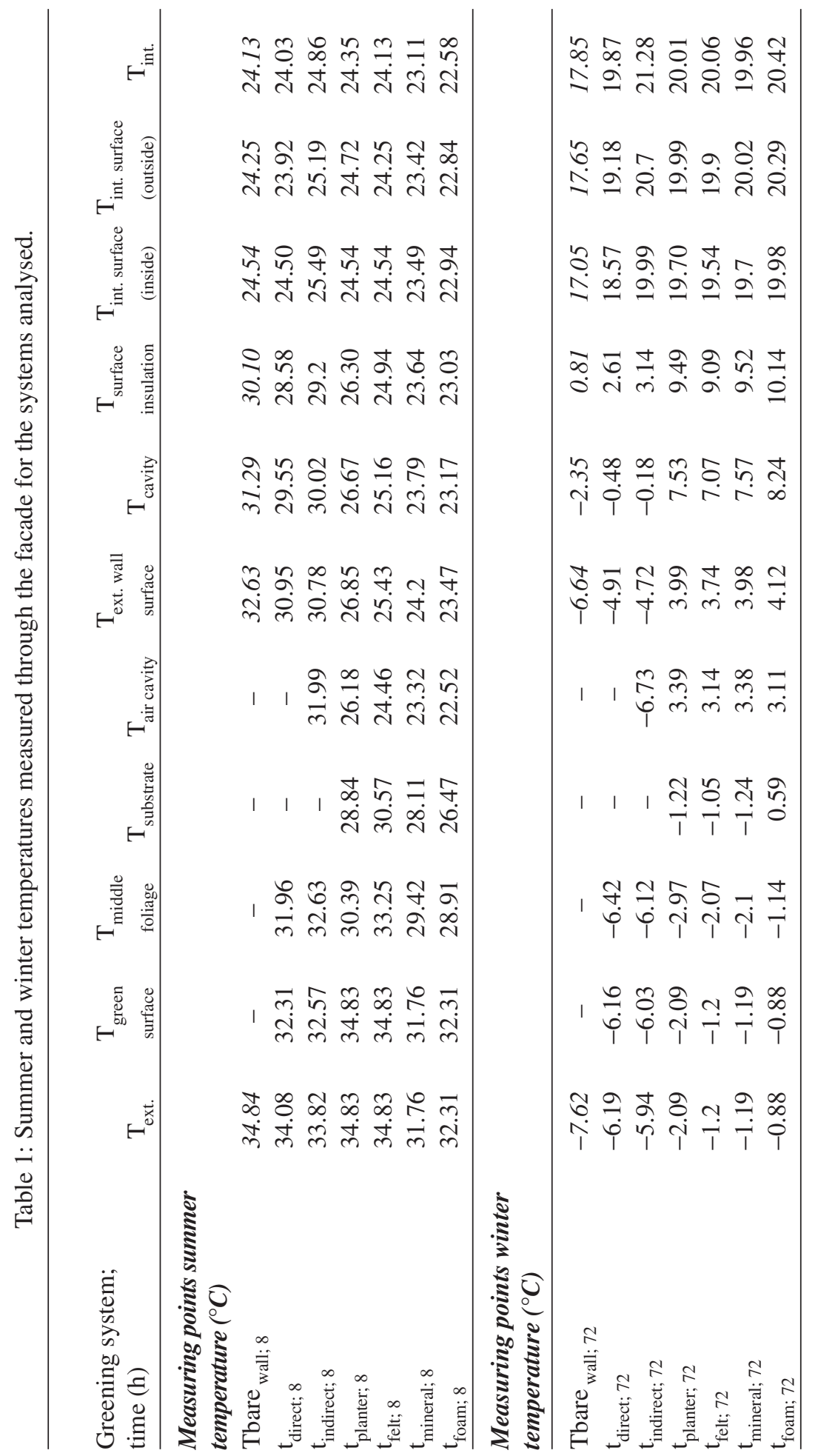


The difference of temperature for the systems is reaching 1.7 and $1.9^{\circ} \mathrm{C}$, respectively, after $8 \mathrm{~h}$ of heating. The insulation material inside the bare wall moderates the prevailing temperature difference between the outside and inside climate chamber, resulting in no temperature difference for the inside climate chamber. The winter measurement after $72 \mathrm{~h}$ shows that the wall surface covered directly with Hedera helix is warmer compared with the bare wall, with a temperature difference of $1.7^{\circ} \mathrm{C}$. The air temperature of the inside climate chamber is lowered with $0.7^{\circ} \mathrm{C}$ in the case of the bare wall, which means that the vegetation layer slows down the rate of heat flow through the façade, resulting in a improved R-value of the system. In the case of the indirect facade greening system, the same trend was found; a temperature difference of $1.9^{\circ} \mathrm{C}$, compared with the bare wall was found and the interior air temperature is lowered with $1^{\circ} \mathrm{C}$ in the case of the bare wall.

According to this measurement, some conclusions can be drawn namely that the insulation material is superior compared with the green layer and, thus, minimizes the effect indoor. However, since the green layer protects the heat accumulation in the outer layer of the masonry, less heat will be re-radiated during the evening and night, which has a positive effect on the urban heat phenomena (lowering the urban temperature).

A stronger relation between temperature reduction and greenery was found for the LWSs tested (Fig. 6). Table 1 shows the results of the temperature development through the facade based on the systems analysed. Interesting to mention is that the surface temperature reduction that can be achieved with the investigated LWSs was between 7.2 and $10.3^{\circ} \mathrm{C}$ during summer conditions. It can be noticed that the effect on the interior temperature is also higher as well as the relation between mitigation of the urban heat island effect.

For the winter measurements, it was found that compared with the bare wall all the greening systems contribute to a better thermal resistance of the facade. Especially in the case of the LWSs higher interior room temperatures were measured up to $4^{\circ} \mathrm{C}$ compared with the bare facade. Which means that the thermal resistance of the greened facades increased due to the extra material properties, air cavity and plant tissue. Field measurements conducted by Mazzali et al. [28] in a Mediterranean climate show comparable findings with laboratory tests and calculations conducted by Ottelé [16]. The facade covered with a living wall consisting an insulation layer (external side of the wall) shows a significant $(66 \%)$ reduction in cooling energy, than a system where the insulation material is on the internal side (more heat accumulation in the massive facade); furthermore, they concluded that the most effective orientation of the (green) cladding, regardless the type of wall and the latitude, was the south side.

\section{ENVIRONMENTAL BURDEN AND SUSTAINABILITY OF VERTICAL GREENING SYSTEMS}

For a sustainable approach, the microclimatic and environmental benefits obtainable have to be related to the environmental burden produced during the whole life span of a vertical greening system. Characteristics, components and materials of vertical greening systems can have an influence not only on the environmental benefits, as above described, but also on the environmental burden produced by a system during its life span [18].

This has been demonstrated by a life cycle analysis, which takes into account the integral balance between the environmental load and possible benefits for a life span of 50 years. The four greening systems analysed in a life cycle analysis conducted by Ottelé et al. [14] are four of the ones described above: a direct greening system (Fig. 5a), an indirect greening system (Fig. 5b), a LWS based on planter boxes (Fig. 6c) and a LWS based on felt layers (Fig. 6d). The results show that there is a significant difference between the greening systems and the bare wall, except for the direct greening system. Figure 7 built up for each system shows the influence for the material classes, transportation and waste of the bare wall, supporting systems and vegetation. The highest difference found in the 
analysis regards the material impact for the supporting systems. Due to this, the direct greening system has the lowest environmental burden. For this system as for the indirect one, also the vegetation has a very small impact, since it is only related to transportation (no watering and nutrients system and replacement of plants is needed). For the LWS based on felt layers, the waste class has a major impact due to the impossibility of recycling the entire module involved. All the systems studied in this analysis reveal similar dominating impact categories, though the magnitude of this differs considerably. This difference is mainly caused by the supporting material and by the durability estimated both for plants and material. Due to this, the LWS based on felt layers has the highest environmental burden, since panels have to be replaced five times in a service life of 50 years.

This is a growing field of study, which has developed rapidly especially in the last three to four years so that various LWSs and greening systems with different materials and characteristics are available [29].

The latter positively or negatively influence the environmental burden. Many types of materials such as different types of wood, plastic, aluminium and steel used to build indirect greening systems can be a support for climbing plants instead of stainless steel mesh. These materials can cause an environmental burden of the system roughly 10 times lower than the stainless steel mesh. Each of the materials enumerated changes the aesthetical and functional properties due to the different weight, profile thickness, durability and cost. Besides this, for LWSs a sustainable approach can involve a higher integration within the building envelope by combining functionalities since the protection against the environmental parameter can be absolved by the layers involved [14].

The study described shows the environmental burden profile in relation with the energy savings for air conditioning and heating. The research conducted by Ottelé et al. [14] takes into account an estimation of the micro-scale benefits of greening systems in a Mediterranean and a temperate climate. To calculate the energy savings for heating, due to the increase of the insulating properties with greening systems, the additional thermal resistance is assumed to be $0.09 \mathrm{Km}^{2} \mathrm{~W}^{1}$. This assumption is used for all of the direct and indirect greening systems analysed due to the stagnant air layer in and behind the foliage, as previously described [27]. For the LWSs, the thermal transmittance
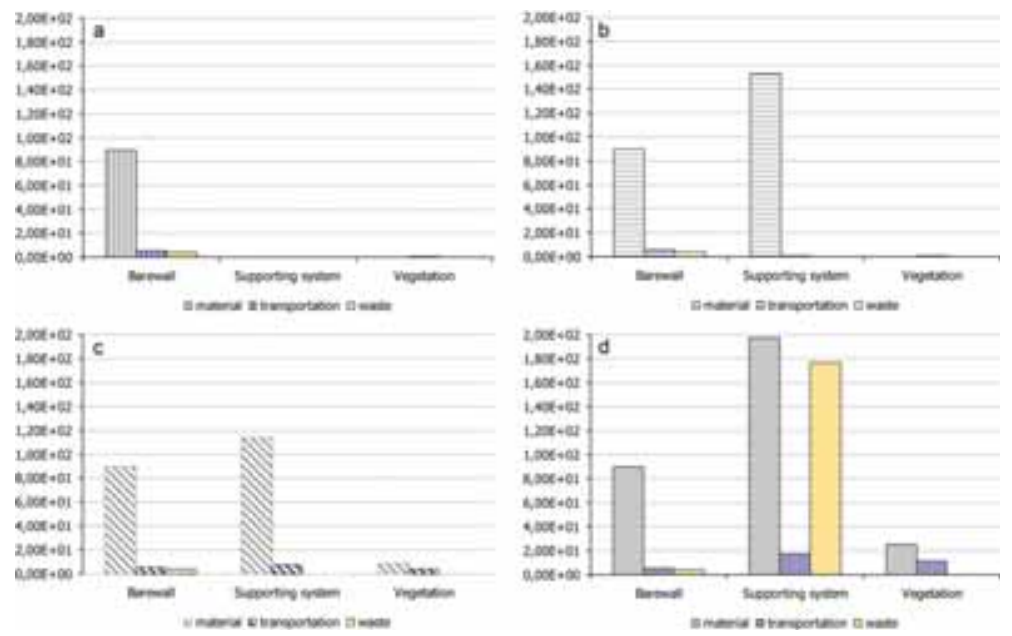

Figure 7: Total environmental burden profile for material classes, transportation and waste for direct greening system (a), indirect greening system based on stainless steel mesh (b), LWS based on planter boxes and (c) LWS based on felt layers (d). 
of the substrate and the materials used are added. The energy saving estimated for the Mediterranean climate thanks to vertical greening systems is roughly two times higher than for temperate climate, due to the role played by air-conditioning systems, even considering that less annual energy consumption for heating is needed. A study conducted by Alexandri and Jones [30] reports a temperature decrease of $4.5^{\circ} \mathrm{C}$ for Mediterranean climate, resulting in $43 \%$ of energy saving for air conditioning. The energy saving for heating has a lower impact on the environmental burden calculation: this is $1.2 \%$ for direct and indirect greening systems, 6.3 for LWS based on planter boxes and $4 \%$ for LWS based on felt layers, according to Perini et al. [27].

Figure 8 shows the relation between the environmental burden and benefits of the systems analysed. Looking to the environmental burden profiles the indirect greening system and the LWS analysed show a major impact (due to the materials used and the life span) even if, as described, the environmental profile can be reduced by more sustainable material choice and an integrated envelope design. For the temperate climate, the environmental burden profile is higher than the energy savings for heating for all the greening systems (supporting system + vegetation), except for the direct greening system that is sustainable (considering a system sustainable when the environmental burden is lower than the environmental benefit profile). For the Mediterranean climate, thanks to the energy savings related to air conditioning, the direct greening system is sustainable and also the LWS based on planter boxes is almost sustainable. For the LWS based on felt layers in both climate types, the environmental burden profile is higher than the benefits gained for heating and cooling. The environmental burden and the benefits for heating and cooling are calculated both for the service life of the greening systems studied.

This life cycle analysis by Ottelé et al. [14] proves that:

- Direct greening systems have a very small influence on the total environmental burden. Thus, this type of greening, without any additional material involved, is always a sustainable choice for the examined cases.

- Indirect greening systems analysed based on a stainless steel supporting system have a high influence on the total environmental burden.

- LWSs based on planter boxes do not have a major environmental footprint due to the materials involved, since the materials affect positively the thermal resistance of the system.

- LWSs based on felt layers have a high environmental burden due to the durability aspect and the materials used.

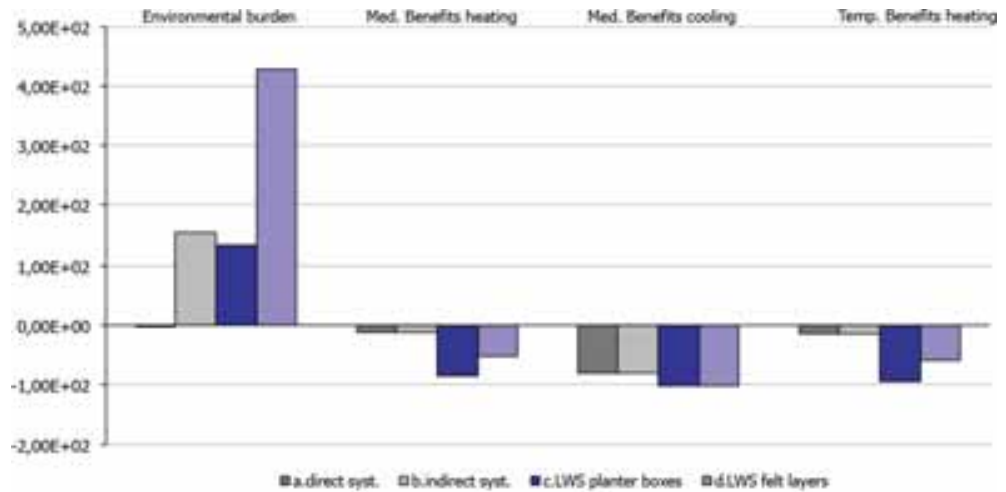

Figure 8: Total environmental burden for four greening systems (supporting systems + vegetation), benefits for heating and cooling for Mediterranean climate and benefits for heating for temperate climate according to Ottelé et al. [14]. 
Material choices are often under estimated by designers, manufacturers of greening systems and architects. An optimal balance has to be found between durability aspects, materials really needed (also by mass, i.e. from sustainability point of view; less is more!) service life and lifespan. More research (since there is a lack of information for these systems) is needed inside this field to evaluate the many other greening systems available on the market.

\section{POTENTIALITIES AND CRITICAL POINTS OF VERTICAL GREENING SYSTEMS}

Characteristics, components and materials of vertical greening systems can have an influence on the environmental burden, environmental benefits, thermal resistance, etc., as described above. The thickness of the air cavity (green layer-façade) and the foliage affects the thermal resistance, as well as other material layers involved [27]. Material choice and durability aspects are important (environmental impact) when the energy demand of a building can be reduced or when the multifunctionality of the construction due to the integration of vegetation can be increased. Therefore, the vertical greening system choice is very important for a sustainable approach [14].

The LWSs can affect positively the thermal resistance of the building envelope, due to the materials involved and to the possibility of combining functionalities, such as insulation material [16, 27]. Green façades with a well-developed climbing plant can provide the reduction of air and surface temperature and, in the case of a façade with openings, also interior shading [17].

Also the costs of the systems play an important role when describing it. As mentioned above LWS are much more expensive than direct and indirect greening systems. This is due to the maintenance needed (nutrients and watering system), the materials involved and the design complexity. A part of the initial costs can be written off thanks to the energy savings for heating and cooling, the aesthetical value of the building, etc. [16]. Also durability aspects play an important role for the economical side. A system such as the living wall based on felt layer (compared with the LWS based on planter boxes) with a lower installation cost could need the replacement of panels every few years [14].

The direct greening system is the most sustainable and cheep one. But some climbing plants only grow 5 or $6 \mathrm{~m}$ high, others around $10 \mathrm{~m}$ and some species at least $30 \mathrm{~m}$ and it takes years to reach a considerable height [3].

\subsection{Maintenance, possible damage and problems}

The use of living material implies the need to consider several variables for the plant species and supporting system choice suitable for every situation to avoid maintenance problems and damage. The risks related to the use of climbing plants (direct and indirect green façades) mainly regard: damage on the building envelope caused by the choice of strong species with branch thickness up to more than $15 \mathrm{~cm}$, supporting structure deformations caused by an inappropriate estimation of the green layer weight, problems caused by the impossibility of maintenance interventions on walls and drying during the winter season (direct climbing plants [13]). A study conducted by Bartfelder and Köhler [24], regarding humidity measurements on a bare façade and on a green one, shows that with a green layer the façade is drier during summer. The LWSs cannot cause damage in this field, since these protect from rain and moisture, thanks to the continuous layer constituted by the greened modular panels.

The possible LWS's problems are connected to the plants survival and growth and, with respect to the building envelope, the disposal of excess water. This aspect requires a special attention to windows, doors and ledges to avoid damage also caused by corrosion. The plants survival depends, in the case of LWS, on the substrate (often inorganic) and on the irrigation system efficiency for water and nutrients demand. The maintenance needs regard, in this case, the eventual replacement of dead plants or whole panels, or of the irrigation system, such as the water pipe replacement that has to be 
done every about seven years (Fig. 9). For direct and indirect green façades, differently, the maintenance needs regard only pruning once or twice per year depending on the growing speed and on the space available. Neglecting these interventions can cause many problems (Fig. 10).

\section{CONCLUSIONS}

The integration of vegetation in the built space can be an opportunity to improve the environmental conditions of dense urban areas and to reduce the energy demand of buildings, especially in Mediterranean area due to its cooling capacity $[3,29]$. This is an important field to investigate considering the growing interest on these systems, connected not only to a more sustainable approach to construction but also to aesthetic intentions [11].

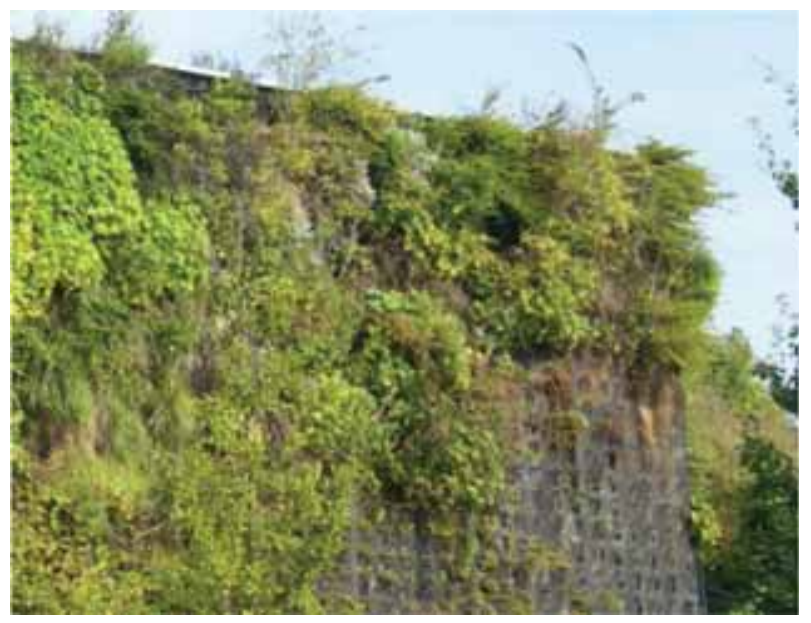

Figure 9: Example of possible damages due to the lack of maintenance and to design mistakes: living wall system based on felt layers in Amsterdam.

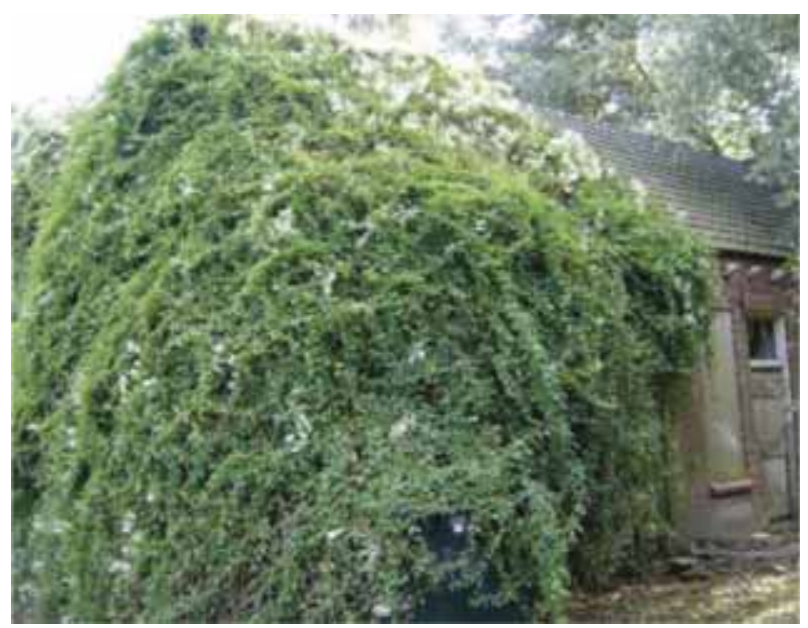

Figure 10: Example of possible damages due to the lack of maintenance: direct green facade with climbing plants. 
To guarantee sustainable practices, benefits and performances obtainable thanks to greening systems have to be considered along with the environmental burden produced during the life span of greening systems, the possible problems connected with maintenance needs. Also costs have to be considered for a wider diffusion of these systems. Measurements carried out in the field by many researchers show the potential of vertical green on the thermal performance. A recent study by Ottelé [16] quantifies the thermal performance of several different greening systems (traditional green facade and LWS) executed under laboratory circumstances (stationary heat flow). Main conclusions are that direct and indirect greenery systems influence the thermal behaviour although the effect is small. In the case of LWSs, the effect on the thermal behaviour is significant and temperature differences of the exterior masonry can be up to $11^{\circ} \mathrm{C}$ under warm temperatures. Also under winter conditions, the thermal resistance of the construction is increased in the case of LWS application; warmer temperatures up to $4^{\circ} \mathrm{C}$ difference compared to the bare wall were measured. The positive effect on the thermal resistance (i.e. summer and winter) is mainly caused by the materials used, extra cavity, water availability and metabolism of the plant tissue. Through (significant) less heat accumulation by the masonry in combination with evapotranspiration caused by the plant material, a positive effect to lower/mitigate the urban heat island effect can be taken into account.

As discussed throughout the article many aspects have to be considered to avoid that green only plays an aesthetic role with respect to sustainability. Characteristics, components and materials of vertical greening systems can have an influence on the environmental burden and environmental benefits, etc. Some systems, as the living wall ones described, offer much more creative and aesthetical potential, but due to the material used and durability in some cases cannot be considered as sustainable. Material choice and durability aspects are important (environmental impact) when the energy demand of a building can be reduced or when the multi-functionality of the construction due to the integration of vegetation can be increased. These aspects have been considered also through a life-cycle analysis [14]. As suggested by Henry and Frascaria-Lacoste [31], the adoption of LCA analysis for the labelling of green products could increase their use since it has the potential to boost the confidence of consumers. Therefore, this could lead to particular focus being placed on specific green elements, which could potentially further homogenize natural features within cities, with possible negative impact on other benefits of green, such as biodiversity [31]. However, a LCA could lead to deeper consideration by manufacturers of the environmental burden produced by their systems to improve the balance between benefits and burden for a more sustainable built environment.

Greening concepts should be considered as a 'building material' with multifunctional properties (ecological, social, mitigation urban heat, etc.) compared with our traditional cladding materials (masonry, concrete, marble, glass, etc.).

Besides it is mandatory to be aware of the cooling and insulation potential of green structures related to energy savings, it contributes to a lower energy demand at the building level and must not be underestimated. This 'total' awareness, which is related to a wider research in this field, will lead to a more eco-friendly and sustainable design of cities.

\section{REFERENCES}

[1] Bohemen van, H., Ecological Engineering, Bridging between Ecology and Civil Engineering, Aeneas Technical Publishers: The Netherlands, 2005.

[2] Köhler, M., Green façades - a view back and some visions. Urban Ecosystems, 11, pp. 423-436, 2008. doi: http://dx.doi.org/10.1007/s11252-008-0063-x

[3] Dunnett, N. \& Kingsbury, N., Planting Green Roofs and Living Walls, Timber Press: Portland, OR, 2008. 
[4] Novi, F., La riqualificazione sostenibile, Alinea Editrice: Firenze, 1999.

[5] Nuzzo, E. \& Tomasinsig, E., Recuperoecoefficiente del costruito, Edicom Edizioni: Monfalcone, Gorizia, 2008.

[6] Thormark, C., A low energy building in a life cycle. Its embodied energy, energy need for operation and recycling potential. Building and Environment, 37(4), pp. 429-435, 2002. doi: http://dx.doi.org/10.1016/S0360-1323(01)00033-6

[7] Ardente, F., Beccali, M., Cellura, M. \& Mistretta, M., Building energy performance: a LCA case study of kenaf-fibres insulation board. Energy and Buildings, 40(2002), pp. 1-10, 2008.

[8] Prasad, D. \& Hill, M., The construction challenge: sustainability in developing countries, London Royal Institution of Chartered Surveyors (RICS) Series, Leading Edge Series, 2004.

[9] Perini, K., Vegetation, architecture and sustainability. Article accepted in EAAE/ARCC International Conference, Milan, 2012. doi: http://dx.doi.org/10.1007/s11252-012-0262-3

[10] Hendriks, C.F., Bijen, J.M.J.M., Felix, F., Fraaij, A.L.A., Janse, H., de Munck, E.D., Reintjes, R.C., Schutte-Postma, E.T., Stroeven, P., Vogtlander, J.G. \& van der Wegen, G.J.L., Durable and Sustainable Construction Materials, Aeneas Technical Publishers: The Netherlands, 2000.

[11] Perini, K., L'integrazione di vegetazione in architettura. Metodi e strumentiinnovativi. The integration of vegetation in architecture. Innovative methods and tools. Dissertation, University of Genoa, 2012.

[12] Perini, K., Ottelé, M., Haas, E.M. \& Raiteri, R., Vertical greening systems, a process tree for green façades and living walls. Urban Ecosystems, 16(2), pp. 265-277, 2013.

[13] Bellomo, A., Paretiverdi, Sistemieditoriali: Napoli, Italy, 2003.

[14] Ottelé, M., Perini, K., Fraaij, A.L.A., Haas, E.M. \& Raiteri, R., Comparative life cycle for green facades and living walls. Energy and Buildings, 43(12), pp. 3419-3429, 2011. doi: http:// dx.doi.org/10.1016/j.enbuild.2011.09.010

[15] Perini, K., Ottelé, M., Haas, E.M. \& Raiteri, R., Greening the building envelope, façade greening and living wall systems. Open Journal of Ecology, 1(1), pp. 1-8, 2011. doi: http:// dx.doi.org/10.4236/oje.2011.11001

[16] Ottelé, M., The Green Building Envelope. Dissertation, Delft University of Technology, 2011.

[17] Wong, N.H., et al., Thermal evaluation of vertical greenery systems for building walls. Building and Environment, 45(3), pp. 663-672, 2009. doi: http://dx.doi.org/10.1016/j. buildenv.2009.08.005

[18] Perini, K. \& Ottelé, M., Vertical greening systems: contribution on thermal behaviour on the building envelope and environmental sustainability. Eco-Architecture IV. Harmonisation between Architecture and Nature, WIT Transactions on Ecology and the Environment, Vol. 165, ed. C.A. Brebbia, Wessex Institute of Technology, WIT Press: UK, 2012.

[19] Krusche, P., Krusche, M., Althaus, D. \& Gabriel, I., Ökologischesbauen. Herausgegebenvomumweltbundesamt: Bauverlag, 1982.

[20] Peck, S.W., Greenbacks from green roofs: forging a new industry in Canada, Status report on benefits, barriers and opportunities for green roof and vertical garden technology diffusion, environmental adaptation research group, Canada, 1999.

[21] Minke, G. \& Witter, G., Häuser mit grünen pelz. Ein handbuch zur hausbegrünung, 1982.

[22] Perez, G., Rincon, L., Vila, A., Gonzalez, J.M. \& Cabeza, L.F., Behaviour of green facades in Mediterranean Continental climate. Energ Convers Manag, 52(4), pp. 1861-1867, 2011. doi: http://dx.doi.org/10.1016/j.enconman.2010.11.008

[23] Minke, G. \& Witter, G., Häuser mit grünen pelz. 3. ed Frankfurt/Main, 1983. 
[24] Bartfelder, F. \& Köhler, M., Experimentelle Untersuchungenzur Funktionvon Fassadenbegrunungen. Förderungsprogramm der Freien, Universitat Berlin fur junge Wissenschaftler 3, Ausschreibung, 1987.

[25] Holm, D., Thermal improvement by means of leaf cover on external walls - a simulation model. Energy and Buildings, 14, pp. 19-30, 1989. doi: http://dx.doi.org/10.1016/03787788(89)90025-X

[26] Eumorfopoulou, E.A. \& Kontoleon, K.J., Experimental approach to the contribution of plant covered walls to the thermal behaviour of building envelopes. Building and Environment, 44, pp. 1024-1038, 2009. doi: http://dx.doi.org/10.1016/j.buildenv.2008.07.004

[27] Perini, K., Ottelé, M., Fraaij, A.L.A., Haas, E.M. \& Raiteri, R., Vertical green systems and their effect on air flow and temperature near the façade. Building and Environment, 45, pp. 2287-2294, 2011. doi: http://dx.doi.org/10.1016/j.buildenv.2011.05.009

[28] Mazzali, U., Peron, F. \& Scarpa, M., Thermo-physical performances of living walls via field measurements and numerical analysis. Eco-Architecture IV. Harmonisation between Architecture and Nature. WIT Transactions on Ecology and the Environment, 165, pp. 239-250, 2012.

[29] Corrado M., Il verdeverticale, Sistemi Editoriali: Napoli, Italy, 2010.

[30] Alexandri, E. \& Jones, P., Temperature decrease in a urban canyon due to green walls and green roofs in diverse climates. Building and Environment, 43, pp. 480-493, 681, 2008.

[31] Henry, A. \& Frascaria-Lacoste, N., Comparing green structures using life cycle assessment: a potential risk for urban biodiversity homogenization? International Journal of Life Cycle Assessment, 17, pp. 949-950, 2012. doi: http://dx.doi.org/10.1007/s11367-012-0462-3 